\title{
The Impact of Investors' Sentiment on the Equity Market: Evidence from Ghanaian Stock Market
}

\author{
Ebenezer Bennet \\ Senior Lecturer \& Head of Department, School of Business Administration \\ All Nations University College, Koforidua, Ghana, West Africa \\ E-mail: bennetebenezer@yahoo.com \\ Lydia Obenewaa Amoako
}

Lecturer, Department of Business Administration, All Nations University College, Koforidua, Ghana, West Africa

E-mail: lobenwaa@gmail.com

Ricky Okine Charles

Lecturer, Department of Business Administration, All Nations University College, Koforidua, Ghana, West Africa E-mail: charlesricky7@gmail.com

Asumadu Edward

Lecturer, Department of Business Administration, All Nations University College, Koforidua, Ghana, West Africa

E-mail: edward.asumadu@allnationsuniversity.org

Joseph Asante Darkwah

Lecturer, Department of Business Administration, All Nations University College, Koforidua, Ghana, West Africa E-mail: darkwahasante@gmail.com

Received: August 9, 2012

Accepted: September 10, 2012

Online Published: September 13, 2012

doi:10.5430/ijba.v3n5p99

URL: http://dx.doi.org/10.5430/ijba.v3n5p99

\begin{abstract}
Investor's Sentiment plays a major role in choosing which stocks we invest. Investors' sentiment can be defined as investors' attitude and opinion towards investing in the Stocks. The aim of this research is to analyse the individual investor's sentiment and also to analyse the influence of Market Specific Factors on investors' sentiment. The investor's attitude towards investing is influenced by rumours, intuition, herd behaviour among investors and media coverage of the stock. 100 investors in Ghana were chosen for the study. These investors were administered a Structured Schedule, containing pre-validated scales to measure the investor sentiment. Once the constructs were found to be both reliable and valid, the impact of Herd Behaviour, Internet Led Access to Information and Trading, Macro Economic Factors, Risk and Cost Factors, Performance Factors and Confidence Level of Institutional Investors, Best Game in Town Factors were tested by using the Bootstrapping method. Few Market Specific Factors had a significant impact on the investors' sentiment in Ghana.
\end{abstract}

Keywords: Investors' sentiment, Best game, PLS path modeling, Market specific factors, Herd behaviour

Ninety percent of what we do is based on perception. It doesn't matter if that perception is right or wrong or real. It only matters that other people in the market believe it. I may know it's crazy, I may think it's wrong. But I lose my shirt by ignoring it.

"Making Book on the Buck"

Wall Street Journal, Sept. 23, 1988, p. 17 


\section{Introduction}

Behavioural Finance can also be defined as the study of investors' attitudes towards investing and its effect on financial markets. In an article in, New York Times dated 06/07/98, the writer says that Behavioural Economists hold the view that investors overvalue private information and undervalue public information. It attributes the growing importance of 'financial emotions' of the average citizen to 'trickle down' to finance. Sophisticated and important financial decision-making is not restricted any more to the rich and the elite. It is now the individual investors who frequently make decisions regarding credit card expenditures, mutual fund investments, retirement plans, mortgages, home equity loans etc. It is through these mundane, daily choices that average individual investors directly affect market conditions, such as inflation rates, interest rates, money supply etc.

The study of market or investors' sentiment has its basis in the theories of Noise Trader Models. (Kyle 1985) and (Black 1986). Both experts suggest that if some traders trade on 'noisy' signals, unrelated to fundamental data, then the market prices may deviate from intrinsic value. The Noise Trader Sentiment can persist in financial markets. They argue that changes in Noise Trader Sentiment must be difficult to predict to avoid arbitrage. The assets that are disproportionally exposed to Noise Trader Risk are both riskier and have to offer an extra return premium. (DeLong, Shleifer, Summers, and Waldmann, 1990).

The research in Behavioural Finance is comparatively less both in Ghana, when compared to other foreign countries. Behavioural Finance is defined by Shleifer, A (1999) as, "a rapidly growing area that deals with the influence of psychology on the behavior of financial practitioners". Behavioural Finance mainly focuses on how investors interpret and act on micro and macro information to make investment decisions. The globalization of financial markets has been increasing the number of retail investors over the past two decades by providing a wide variety of market and investment options. However, it makes the investment decisions process much more complex.

The retail investors generally consider their investment needs, goals, objectives and constraints while making investment decisions. But it is not possible for them to make a successful investment decision at all times. Their attitude is influenced by a variety of factors such as dividend, get rich quickly strategy, stories of successful investors, online trading, investor awareness programme, etc. A better understanding of behavioral processes and outcomes are important for financial planners because an understanding of how investors generally respond to market movements would help them in devising appropriate asset allocation strategies for clients. (Hussein et al 2006).

The Ghanaian stock market has been around for close to two decades. The creation of the Ghana Stock Exchange was part of the recommendations of the economic reforms carried out in the 1980s to generate sustainable economic growth and development.

Stock Markets in any country would boost domestic savings and increase the investments. Hence with the same objective in mind stock markets are opened in Africa. Generally, stock markets are seen as enhancing the operations of the domestic financial system in general and the capital market in particular (Kenny and Moss, 1998). However, it is also argued that the stock market might not perform efficiently in developing countries and that it may not be feasible for all African markets to promote stock markets given the huge cost and the poor financial structures (Singh, 1999).

Various studies have been conducted in other countries but there is no comprehensive study covering Investors' Sentiment on Equity in Ghana. Hence this study attempts to find out the Impact of Investors' Sentiment on the Equity Market in Ghana.

\section{Literature Review}

The following are the select earlier research studies conducted in the area of Behavioural Finance. David S. Scharfstein and Jeremy C. Stein (1990), in their article titled, "Herd Behaviour and Investment", examined some of the forces that can lead to herd behaviour in investment. The study found that under certain circumstances, the managers simply mimic the investment decisions of other managers, ignoring substantive private information. Although this behaviour is inefficient from a social standpoint, it can be rational from the perspective of managers who are concerned about their reputations in the labour market. An article entitled, "An Examination of Herd Behavior in Equity Markets: An International Perspective", authored by Eric C. Chang, Joseph W. Cheng and Ajay Khorana (2000) examined the investment behavior of market participants in different international markets namely US, Hong Kong, Japan, South Korea, and Taiwan, specifically with regard to their tendency to exhibit herd behavior. It found no evidence of herding on the part of market participants in the US and Hong Kong and found partial evidence of herding in Japan. However, for South Korea and Taiwan, the study found significant evidence of herding. 
Brad M Barber and Terrance Odean (2001), in their paper titled, "The Internet and the Investor", found that the internet has changed the process of how information is delivered to the investors and the ways in which investors can act on that information. The ILA has lowered both the fixed and marginal costs of producing financial services, thus enabling newer, smaller companies to challenge the established providers of these services. The paper entitled, "Behavioral Finance: Is Investor Irrationality the Norm?", by Shailaja Gajjala (2005), identified investment biases possessed by retail investors. The study found that $90 \%$ of the sample reported that their current and future investment decisions were dependent on their past choices. Finally, the study found the evidence of retail investment biases that lend credence to the proponents of Behavioral Finance. The paper entitled, "Investor Sentiment and Stock Market Response to Corporate News", by G. Mujtaba Mian, and Srinivasan Sankaraguruswamy (2008), examined whether market-wide investor sentiment influences the stock price response to firm-specific news. The results indicate that the prevailing sentiment sways stock price response to news in the direction of the sentiment - the positive stock price response to good news and increase with sentiment, whereas the negative stock price response to bad news and decrease with sentiment. A paper entitled, "Market Response to Investor Sentiment", by Jördis Hengelbrock Erik Theissen Christian Westheide (2010), suggested that measures of investor sentiment have predictive power for future stock returns over the intermediate and long term. The study suggested that smart investors should trade on the information conveyed by such indicators and thus triggered an immediate market response to their publication. The paper entitled, "Investor Sentiment and Real Investment", by David McLean and Mengxin Zhao (2010), studied the effects of systematic investor sentiment on investment and external finance over a 44-year period. Sentiment causes both investment and external finance to be more sensitive to growth opportunities and less sensitive to cash flow. The findings are broadly consistent with a sentiment-costly, external financing framework in which sentiment affects the prices of risky securities. Bennet and Selvam, (2011) found out that SPERTEL risks had influenced the value of equity shares in the market. The market factors had influenced the stock selection Decision of Retail Investors in India. Bennet et al (2011) carried out a study and found that most of the investors expect the stock prices to go up to a degree greater than most of their investments. If the market has gone down, they think it would rebound. If the market is up, they think it would go further. In either case, they make investment decision on account of the assumption that the stock market would give better returns. It is to be noted that the literature on investor's sentiment is still in its infancy, and much remains to be discovered and learnt. There is no comprehensive study in Tamil Nadu, India, focussing on market specific factors that influence investors' sentiment. Hence this study, with the primary objective of analysing data on individual equity investors, proposes to identify the market specific factors that influence investors' sentiment.

\section{Market Factors / Variables That Influence Investors' Sentiment}

The market factors (variables) that influence the investors' sentiment are briefly described below:

3.1 Herd Behaviour refers to similarity in thinking among individual investors. It describes how individuals in a group can act together without planned direction. If well informed and experienced investors invest in a particular stock, the other investors, without analyzing the market and other factors, would also follow the same.

3.2 Internet Led Access to Information and Trading (ILA): It is generally felt that the new generation of investors are techno-savvy, self reliant and buy and sell like professionals. Such investors are hungry for more information and demand information at a higher level than in the past and trade frequently. The internet has facilitated easy, low cost and speedy access to information and trading. Brad M Barber and Terrance Odean (2001) found that the internet has changed the process of how information is delivered to the investors and the ways in which investors can act on that information. The ILA has lowered both the fixed and marginal costs of producing financial services, thus enabling newer, smaller companies to challenge established providers of these services.

3.3 The Macro Economic Factors (MEF) that could influence the investors' attitudes towards investing in Ghana are Interest Rate, Rate of Inflation, Unemployment Rate, Strength of Indian Economy and the Value of other Major Currencies. Mark J. Flannery Aris A. Protopapadakis (2002) found that the stock market returns were significantly correlated with inflation and money growth. The impact of real macroeconomic variables on aggregate equity returns has been difficult to establish.

3.4 Risk and Cost Factors (RCF): Investors have identified two factors as most important; the first one is cost cutting at the operations level and the second being technological advancement. Similarly they also identified two aspects of risk that influenced the investor's attitude. First investors believe that higher the risk, higher the return. Secondly, investors view the stability and the able governance of the Government as an important factor influencing their faith in the Stock Market. 
3.5 Performance Factor and Confidence Level of Institutional Investors (PFCII): The overall performance of the Ghanaian Economy, Ghanaian Stock Market and the corporate world were identified as the important factors that would influence the Individual Investors to invest in the Stock Market. The overall confidence level of the Institutional Investors was also considered as another factor.

3.6 Best Game in Town: The Stock Market is considered as the only best place attracted to invest and it has become a national pastime and hence it is considered as the Best Game in Town.

An attempt has been made in this study to examine the market specific factors that influence the investors' sentiment to invest in stock market. All the above six market factors are considered in this study as independent variables.

\section{Hypothesis of the Study}

Investors' optimism that 'nothing can go wrong attitude' is that they believe the stock prices to rise for the next 12 months and they plan to increase their investment in the Ghanaian Stock Market for the next 12 months also. Hence the following hypothesis was formulated and tested.

Investors' Optimism is influenced by Herd Behaviour of Investors (HB), Internet Led Access to Information and Trading (ILA), Macro Economic Factors (MEF), Risk and Cost Factor (RCF), Performance Factor and Confidence Level of Institutional Investors (PFCII) and Best Game in Town (BG).

\section{Methodology of the Study}

\subsection{Data Collection and Instrument Administered}

The instrument used for this study consists of six constructs (independent variables), namely, Herd Behaviour of Investors, Internet Led Access to Information and Trading, Macro Economic Factors, Risk and Cost Factor, Performance Factor and Confidence Level of Institutional Investors, Best Game in Town and Investors' Optimism is taken as a Dependent Variable (another construct). These seven constructs were already developed and validated by Shiller's (1999) and used by Vandana Singhvi (2001) Bennet Ebenezer (2011).

\subsection{Sources of Data}

The research design for the study was descriptive in nature. The Researchers depended heavily on primary data. The required data were collected from the retail investors living in Ghana through a Structured Interview Schedule. The study was conducted during the period between July and September, 2011.

\subsection{Sampling Size and Procedure}

In order to collect the required information from the retail investors, the sampling design was carefully decided and properly chosen for the study. The sample size covered 100 retail investors who were spread through three different investment centres in Ghana. The important places where large investors are available were identified as Investment Centres, for this study using Purposive Sampling Method. The three important places in Ghana were Accra, Tema and Koforidua.

\subsection{Variables Used}

Dependent variables: This study consists of the following Dependent Variables

i. Stock prices in Ghana will rise in the next 12 months.

ii. I plan to increase my investment in the Ghanaian Stock Market in the next 12 months.

Independent Variables: The study consists of six Market Specific Factors influencing Investors Sentiment. The in-depth interviews and secondary research identified six multi-item market specific factors that possibly influenced investors' attitude towards investing. In the survey, the sample respondents were asked to rate each item on a one (not important) to seven (very important) point scale indicating the extent to which they thought each of the item is likely to influence the individual investor's attitude towards investing. The idea was to get the relative importance of market factors likely to influence investors' sentiment. This rating was used to list the independent market variables that could impact investors' sentiment. The six multi-item market specific factors are Herd Behaviour of Investors (HB), Internet Led Access to Information and Trading (ILA), Macro Economic Factors (MEF), Risk and Cost Factor (RCF), Performance Factor and Confidence Level of Institutional Investors (PFCII) and Best Game in Town (BG).

\subsection{Reliability Test}

Tables 1 to 7 show the value of reliability (Alpha) test for market factor. As stated earlier, each market specific factor has variables. While arriving at the alpha value for each factor, all 28 variables were considered. The reliability value of each market factor was ascertained (Herd Behaviour (HB) Alpha $=0.898$. Internet led access to Information and 
Trading (ILA) Alpha $=0.873$. The Macroeconomic factors (MEF) Alpha $=0.911$. Risk and Cost Factor (RCF) Alpha $=0.869$. Performance Factor and Confidence Level of Institutional Investors (PFCII) Alpha $=0.769$ and Best Game in Town $(\mathrm{BG})$ - Alpha $=0.618$ ). The reliability of each construct in question was examined using Cronbach's alpha (Cronbach, 1951). An alpha score, larger than 0.5 is generally acceptable as sufficient accuracy for a construct (Nunnally, 1978). Hence all the constructs are considered to be very good as the alpha value of each construct was more than 0.5 .

It is to be noted that after the data the collection, the scales were analyzed to test the purification of scales, reliability of scales, unidimensionality of scales and validity of the scales. The purification was done using Corrected Item Total Correlation (CITC), reliability was tested using Cronbach's Alpha while validity and unidimensionality were tested using PLS Path Modeling. Before any type of factor analysis was done (Exploratory Factor Analysis, EFA or Confirmatory Factor Analysis, CFA), it was essential to purify the measuring instruments of variables that did not correlate to the constructs (Churchill, 1979). The purification is carried out by inspecting the CITC values of each variable with respect to the construct to which it belongs. CITC indicates whether the variable actually belongs to the construct or not. The variables showing scores lower than 0.5 were deleted, unless there was a compelling reason to keep them in the construct. Reliability of constructs refers to the accuracy with which the constructs repeatedly measure the same phenomenon without much variation.

\section{The Results of Structural Equation Model}

In this study, Researchers employed Structural Equation Modeling to test the unidimensionality of the constructs. There are two approaches to Structural Equation Modeling-- Covariance Methods and PLS Path Modeling. Covariance methods make rigid assumptions about the distribution of variables (multivariate normality) and the sample size (at least 200). Another criterion is the degrees of freedom, which means that each construct should have at least three indicators for it to be identified. These three indicators do not make any assumptions about the distribution of the data, and the sample size needed for model validation and testing is much smaller. The convergent validity of each construct is checked by examining the Average Variance Extracted' (AVE) values. Constructs, which have AVE values greater than 0.5 , are said to have convergent validity or unidimensionality. In some cases, values up to 0.4 are also considered if they are central to the model (Chin, 1995 and 1998; Chin and Newsted, 1999; and Chin et al., 2003). The Discriminant Validity of Constructs is ascertained by comparing the AVE scores of two constructs, with the square of the correlation between the two constructs. If both the AVE values are larger than the square of the correlation, the constructs can be considered to show Discriminant Validity (Fornell and Larcker, 1981).

\section{Construct Level Correlation Analysis of Model}

In order to test the proposed hypotheses, this study employed a Construct Level Correlation Analysis as an initial verification. Visual PLS was used to compute the construct scores. The Construct Level Correlation Analysis in variables has been presented in Table 8. According to the above Table, there exists a positive correlation between the HB and IO ( $(\mathrm{r}=0.651)$, ILA and IO ( $\mathrm{r}=0.868)$, MEF and IO ( $\mathrm{r}=0.876)$, RSF and IO ( $\mathrm{r}=0.802)$, PFCII and IO (r=0.761) and $\mathrm{BG}$ and IO $(\mathrm{r}=0.610)$. The correlation coefficient between HB and IO, ILA and IO, MEF and IO, RSF and IO, PFCII and IO and BG were positively significant at 0.01 per cent level.

Though the bivariate correlations were significant between the constructs, it was still needed to assess the path coefficients in the structural model as a casual effect. Path coefficients in PLS are standardised regression coefficients (Staples et al., 1998). In order to ensure that path coefficients are statistically significant, this study used a Bootstrap and Jack-Knife re-sampling procedures to estimate standard errors for calculating T values using Visual PLS. The results were examined at 5 per cent significance level and the t-statistic value at 0.05 level was 1.96 . If the t-statistic value is greater than 1.96, the path is significant (Efron 1979, Efron and Gong 1983).

\subsection{Testing of Hypothesis}

The Bootstrap Summary was used to test the relationship between the independent (Market Specific Factors) and dependent variables (IO).The results of Bootstrap Summary for Market Specific Factors and Investor Optimism are given in Table - 9 The hypotheses one to six concern the relationships between HB, ILA,MEF, RSF, PFCII, BG and the outcome variable of IO. These hypotheses were tested using PLS-PM procedure in Visual PLS Software.

\section{$H_{1}$ : Investors' Optimism is influenced by Herd Behaviour (HB)}

The path linking HB to the extent of usage of IO was not found to be significant and it was also negatively related at 0.05 level $($ Beta $=-0.0508, \mathrm{t}=-3.0252)$. This indicates that $\mathrm{HB}$ did not influence the extent of usage of IO in Investors' Sentiment. 


\section{$\mathrm{H}_{2}$ : Investors' Optimism is influenced by Internet Led Access to Information and Trading (ILA)}

According to the table (9), the path linking ILA to the extent of usage of IO was not significant at 0.05 level (Beta $=$ $0.2210, t=1.2243)$. This result reveals that Internet Led Access to Information \& Trading did not influence the Investor Optimism.

\section{$H_{3}$ : Investors' Optimism is influenced by Macro Economic Factors (MEF)}

The path linking MEF to the extent of usage of IO was found to be positively significant at 0.05 level (Beta $=1.0360$, $\mathrm{t}=5.6088)$. This indicates that MEF highly influenced the Investor Optimism.

\section{H4: Investors' Optimism is influenced by Risk and Cost Factors (RCF)}

As given in table (9), the path linking RCF to the extent of usage of IO was not significant and it is also negatively related at 0.05 level (Beta $=-0.0310, t=-0.4151$ ). This indicates that RCF does not influence the extent of usage of IO in Investors' Sentiment.

\section{H5: Investors' Optimism is influenced by Performance Factor and Confidence Level of Institutional Investors (PFCII)}

The path linking PFCII to the extent of usage of IO was found to be positively significant at 0.05 level $($ Beta $=$ $-0.2420, \mathrm{t}=-2.2320$ ). This result reveals that IO was influenced by PFCII.

\section{H6: Investors' Optimism is influenced by Best Game in Town (BG)}

It is found that the path linking BG to the extent of usage of IO was positively significant at 0.05 level $($ Beta $=$ $0.3390, \mathrm{t}=3.1138$ ). This indicates that IO was highly influenced by BG.

The validation of model is given in Figure 1. It is understood from the above figure that out of six market specific factors, two factors, namely, Macro Economic Factors, and Best Game in Town registered positive and significant relationship with the dependent variable of IO. But, the other four factors, namely, Herd Behaviour of Investors, Internet Led Access to Information and Trading (ILA), Performance Factor and Confidence Level of Institutional Investors (PFCII) and Risk and Cost Factors, recorded inverse relationship with the dependent variable of IO.

\subsection{Discussion}

As stated earlier, Herd Behaviour (HB) refers to similarity in thinking among individuals. If well informed and experienced investors invest in a particular stock, then the other investors would also follow the same. This has already been established by Vandana Singhvi (2001) in her study. But the findings of the study conducted in India E.Bennet (2011) and our current study varies from Vandana Singhvi's findings. The present study found that HB did not influence the extent of usage of Investors' Optimism towards Investors' Sentiment. This could possibly be due to the knowledge level of the Investors. The reason for the contrary conclusion is that now a days, the new generation of investors use fundamental analysis and technical analysis before they invest in stock market.

Internet Led Access to Information and Trading (ILA): The new generation of investors buy and sell stocks like professionals. The internet has facilitated easy, low cost and speedy access to information and trading. The findings of the Indian study was also in line with the findings of Freund, Caroline L. and Weinhold, Diana (2001) and Brad M Barber and Terrance Odean (2001). But the current study conducted in Ghana has a contradicting result, possibly because online trading is not very familiar still.

According to our study, variables under Macroeconomic factors (MEF) namely, Interest Rate, Rate of Inflation and Strength of Indian Economy influenced investors' attitude towards investing in Ghana. This finding of both the Indian study and Ghanian Study were in line with the study of Vandana Singhvi (2001) and Mark J. Flannery Aris A. Protopapadakis (2002).

It is found that both the Study conducted in India by E. Bennet and the current study in Ghana, Risk and Cost Factors did not influence the Investors' Optimism.

In our study, the Investor Optimism is not influenced by Performance Factor and Confidence Level of Institutional Investors (PFCII) similar to that of the study conducted in India.

In the same way, IO is influenced by the belief that there is no alternative investment option other than the stock market. The stock market is considered as the Best Game in Town. This finding coincides with the earlier study conducted by both Vandana Singhvi (2001) in USA and Bennet (2011) in India. 


\section{Conclusion}

The investors optimistic about Ghanian Stock market's ability to perform well even if there is a slight down fall. As witnessed in the stock market in the past few years, individual investors looked for buying opportunities each time a favourite stock fell. Since the cost of trading is low, the investors would buy each time the when price dipped. This ensured that any minor dips are unsustainable for these stocks. The factors influencing investors' expectation of stock prices rising for the next 12 months are the low rate of inflation, interest rate, unemployment rate and price of fuel.

The investor optimism or 'nothing can go wrong attitude' is reflected in the belief that there is no alternative investment option other than the stock market and the stock market is the best game in town. It is also found from the interactions with select investors that Provident Fund and Gratuity would not be able to cover the investors old age / retirement life. Therefore to manage the retirement / old age, the investors know that they would need to save and invest in Stock Market. Out of various vehicles to invest, the investors find the Ghanaian stock market to be very attractive. The low returns offered by Post Office, Government Bonds etc, make them relatively unattractive and persuade them to invest in Stocks.

\section{References}

Bennet E., \& Selvam M. (2011). Factors Influencing Retail Investors Attitude Towards Investing In Equity Stocks: A Study In Tamil Nadu. J. of Modern Accounting and Auditing, 7(3), 316-321.

Bennet E., \& Selvam M. (2011). Investors' perception towards the influence of SPERTEL risks on the value of equity shares. A Study conducted at Coimbatore City. International Journal of Research in Commerce and Management, 1(2), 62-66.

Black, Fisher. (1986). Noise. The J. of Finance, 41(3), 529-543. http://dx.doi.org/10.1111/j.1540-6261.1986.tb04513.x

Brad M Barber, \& Terrance Odean. (2001). The Internet and the Investor. J. of Economic Perspectives, 15(1), 41-54. http://dx.doi.org/10.1257/jep.15.1.41

Chin W. W. (1995). Partial Least Squares is to LISREL as Principal Components Analysis is to Common Factor Analysis. Technology Studies, 2(2), 315-319.

Chin W. W. (1998). The Partial Least Squares Approach for Structural Equation Modelling. In George A Marcoulides (Ed.), Modern Methods for Business Research (3, 448). Lawrence Erlbaum Associates.

Chin W. W., \& Newsted P. R. (1999). Structural Equation Modeling Analysis with Small Samples Using Partial Least Squares. In Rick Hoyle (Ed.), Statistical Strategies for Small Sample Research (14, 189-217). New Delhi: Sage Publications.

Chin W. W., Marcolin B. L., \& Newsted P. R. (2003). A Partial Least Squares Latent Variable Modeling Approach for Measuring Interaction Effects: Results from a Monte Carlo Simulation Study and an Electronic- Mail Emotion/Adoption Study. Information Systems Research, 307-340.

Cronbach L. J. (1951). Coefficient Alpha and Internal Structure of Tests. Psychometrika, 16, 297-334. http://dx.doi.org/10.1007/BF02310555

David McLean, \& Mengxin Zhao. (2010). Investor Sentiment and Real Investment. [Online] Available: http://ssrn.com/abstract=1475663

De Long, J. B., Shleifer, A., Summers, L., \& Waldmann, R. (1990). Noise Trader Risk in Financial Markets. J. of Political Economy, 98, 703-738. http://dx.doi.org/10.1086/261703

Eric C. Chang, Joseph W Cheng, \& Ajay Khorana. (2000). An Examination of Herd Behaviour in Equity Markets: An International Perspective. J. of Banking and Finance, 24(10), 1651-1679. http://dx.doi.org/10.1016/S0378-4266(99)00096-5

Fornell Claes, \& Larcker David F. (1981). Evaluating Structural Equation Models with Unobservable Variables and Measurement Error. J. of Marketing Research, 18, 39-50. http://dx.doi.org/10.2307/3151312

Freund, Caroline L., \& Weinhold, Diana. (2000). On the Effect of the Internet on International Trade. FRB International Finance Discussion Paper No 693. [Online] Available: http://ssrn.com/abstract=260238

Jördis Hengelbrock, Erik Theissen, \& Christian Westheide. (2010). Market Response to Investor Sentiment. [Online] Available: http://ssrn.com/abstract $=1343798$ 
Kahnemann D., \& A. Tversky. (1979). Prospect Theory: An Analysis of Decision Under Risk. Econometrica, 47, 263-91. http://dx.doi.org/10.2307/1914185

Kenny, Charles, \& Todd D. Moss. (1998). Stock Market in Africa: Emerging Lions or White Elephants? World Development, 26, 29-43. http://dx.doi.org/10.1016/S0305-750X(98)00019-9

Mujtaba Mian, \& Srinivasan Sankaraguruswamy. (2008). Investor Sentiment and Stock Market Response to Corporate News. [Online] Available: http://ssrn.com/abstract= 107619

Scharfstein, David S., \& Jeremy C. Stein. (1990). Herd Behaviour and Investment. The American Economic Review, 80(3), 465- 479 .

Shailaja Gajjala. (2005). Behavioral Finance: Is investor Irrationality the norm? Osmania J. of Management, 2(2), 13-20.

Singh, Ajit. (1999). Should Africa promote Stock Market Capitalism? Journal of International Development, 11, 343-365. http://dx.doi.org/10.1002/(SICI)1099-1328(199905/06)11:3<343::AID-JID593>3.0.CO;2-Q

Vandhana Singhvi. (2001). Investors' Sentiment: Its various Measurements and Dimensions. Ph.D Thesis (Unpublished ). New York: New York University.

Table 1. Corrected Item- total correlation for dependent variables

\begin{tabular}{|l|c|}
\hline \multicolumn{1}{|c|}{ Variables } & $\begin{array}{c}\text { Corrected Item-Total } \\
\text { Correlation 1 }\end{array}$ \\
\hline Stock prices in Ghana will rise in the next 12 months & 0.785 \\
\hline I will stay invested in the Ghana Stock Market even during Crisis. & 0.838 \\
\hline $\begin{array}{l}\text { I plan to increase my investment in the Indian Stock market in the } \\
\text { next 12 months. }\end{array}$ & 0.848 \\
\hline Cronbach's alpha & $\mathbf{0 . 8 5 7}$ \\
\hline
\end{tabular}

Source: Calculated from primary data using VISUAL PLS.

Table 2. Corrected item- total correlation for herd behaviour of investors

\begin{tabular}{|l|c|}
\hline \multicolumn{1}{|c|}{ Variables } & $\begin{array}{c}\text { Corrected Item-Total } \\
\text { Correlation 1 }\end{array}$ \\
\hline Stories of successful Investors & 0.810 \\
\hline Perception of easy money among Investors & 0.750 \\
\hline Get rich quick Philosophy & 0.821 \\
\hline Greed among Investors & 0.829 \\
\hline Media focus on Stock Market & 0.821 \\
\hline Performance of Internet Stocks & 0.773 \\
\hline Cronbach's alpha & $\mathbf{0 . 8 9 8}$ \\
\hline
\end{tabular}

Source: Calculated from primary data using VISUAL PLS. 
Table 3. Corrected item- total correlation for internet led access to information and trading

\begin{tabular}{|l|c|}
\hline \multicolumn{1}{|c|}{ Variables } & $\begin{array}{c}\text { Corrected Item-Total } \\
\text { Correlation }\end{array}$ \\
\hline On-line trading & .739 \\
\hline Information age, access to information & .843 \\
\hline Access to tools and technology via the internet & .898 \\
\hline Ease of executing a Trade & .889 \\
\hline Low cost of executing a trade & .722 \\
\hline Cronbach's alpha & $\mathbf{0 . 8 7 3}$ \\
\hline
\end{tabular}

Table 4. Corrected item- total correlation for macro economic factors

\begin{tabular}{|l|c|}
\hline \multicolumn{1}{|c|}{ Variables } & $\begin{array}{c}\text { Corrected Item-Total } \\
\text { Correlation }\end{array}$ \\
\hline Interest Rate & 0.646 \\
\hline Availability of Corporate Research & 0.794 \\
\hline Rate of Inflation & 0.849 \\
\hline Price of Fuel & 0.817 \\
\hline Financial Experts Remarks & 0.866 \\
\hline Unempolyment Rate & 0.7236 \\
\hline Strength of Ghanian Economy \$ VS other major currencies & 0.759 \\
\hline Mergers and Acquisitions in the Corporate Sector & $\mathbf{0 . 8 0 9}$ \\
\hline Cronbach's alpha & $\mathbf{0 . 9 1 1}$ \\
\hline
\end{tabular}

Table 5. Corrected item- total correlation for risk and cost factors

\begin{tabular}{|l|c|}
\hline \multicolumn{1}{|c|}{ Variables } & $\begin{array}{c}\text { Corrected Item-Total } \\
\text { Correlation }\end{array}$ \\
\hline Political Stability & 0.782 \\
\hline Investors' tolerance for risk & 0.894 \\
\hline Technological advancement at Company Level & 0.876 \\
\hline Cost cutting at the operations level & 0.871 \\
\hline Cronbach's alpha & $\mathbf{0 . 8 6 9}$ \\
\hline
\end{tabular}

Source: Calculated from primary data using SPSS 16. 
Table 6. Corrected item- total correlation for performance factors and confidence level of institutional investors

\begin{tabular}{|l|c|}
\hline \multicolumn{1}{|c|}{ Variables } & $\begin{array}{c}\text { Corrected Item-Total } \\
\text { Correlation }\end{array}$ \\
\hline Confidence level of Institutional Investors & 0.894 \\
\hline Strength of Ghanian Economy vs major economies & 0.724 \\
\hline Performance of the Indian Stock Market & 0.724 \\
\hline Cronbach's alpha & $\mathbf{0 . 7 6 9}$ \\
\hline
\end{tabular}

Source: Calculated from primary data using VISUAL PLS.

Table 7. Corrected item- total correlation for Best Game in Town

\begin{tabular}{|l|c|}
\hline \multicolumn{1}{|c|}{ Variables } & $\begin{array}{c}\text { Corrected Item-Total } \\
\text { Correlation }\end{array}$ \\
\hline Can't depend on Provident Fund / Gratuity/ Post Office Savings etc & 0.775 \\
\hline Low rate of return in Government Bonds & 0.752 \\
\hline Target Savings Rate & 0.741 \\
\hline Cronbach's alpha & $\mathbf{0 . 6 1 8}$ \\
\hline
\end{tabular}

Source: Calculated from primary data using VISUAL PLS.

Table 8. Construct level correlation analysis of model

\begin{tabular}{|c|c|c|c|c|}
\hline Hypothesis & $\begin{array}{l}\text { Independent } \\
\text { Variable }\end{array}$ & Dependent Variable & $\begin{array}{l}\text { Pearson } \\
\text { Correlation }\end{array}$ & Sig. (2 Tailed) \\
\hline $\mathrm{H}_{1}$ & $\mathrm{HB}$ & \multirow{6}{*}{$\begin{array}{c}\text { INVESTOR } \\
\text { OPTIMISM (IO) }\end{array}$} & 0.651 & $0.000^{* *}$ \\
\hline $\mathrm{H}_{2}$ & ILA & & 0.868 & $0.000^{* *}$ \\
\hline $\mathbf{H}_{3}$ & MEF & & 0.876 & $0.000^{* *}$ \\
\hline $\mathbf{H}_{4}$ & RSF & & 0.802 & $0.000 * *$ \\
\hline $\mathbf{H}_{5}$ & PFCII & & 0.761 & $0.000 * *$ \\
\hline $\mathrm{H}_{6}$ & BG & & 0.610 & $0.000^{* *}$ \\
\hline
\end{tabular}

Source: Calculated from primary data using VISUAL PLS. 
Table 9. Boot strap summary for stock specific factors and investor optimism

\begin{tabular}{|c|c|c|c|c|c|c|}
\hline Hypothesis & Entire & Mean of & Standard & T-Statistic & R Square & Result \\
& Sample & Sub & Error & & Value & Insignificant \\
\hline $\mathrm{H}_{1}$ & -0.5080 & -0.5034 & 0.1679 & -3.0252 & & Insignificant \\
\hline $\mathrm{H}_{2}$ & 0.2210 & 0.2619 & 0.1805 & 1.2243 & \multirow{2}{*}{ Significant } \\
\hline $\mathrm{H}_{3}$ & $\mathbf{1 . 0 3 6 0}$ & $\mathbf{1 . 0 1 7 0}$ & $\mathbf{0 . 1 8 4 7}$ & $\mathbf{5 . 6 0 8 8}$ & & \multirow{2}{*}{ Insignificant } \\
\hline $\mathrm{H}_{4}$ & -0.0310 & -0.1079 & 0.0747 & -0.4151 & & \\
\hline $\mathrm{H}_{5}$ & -0.2420 & -0.2466 & 0.1084 & -2.2320 & & Insignificant \\
\hline $\mathrm{H}_{6}$ & $\mathbf{0 . 3 3 9 0}$ & $\mathbf{0 . 3 3 5 7}$ & $\mathbf{0 . 1 0 8 9}$ & $\mathbf{3 . 1 1 3 8}$ & & Significant \\
\hline
\end{tabular}

Source: Calculated from primary data using VISUAL PLS.

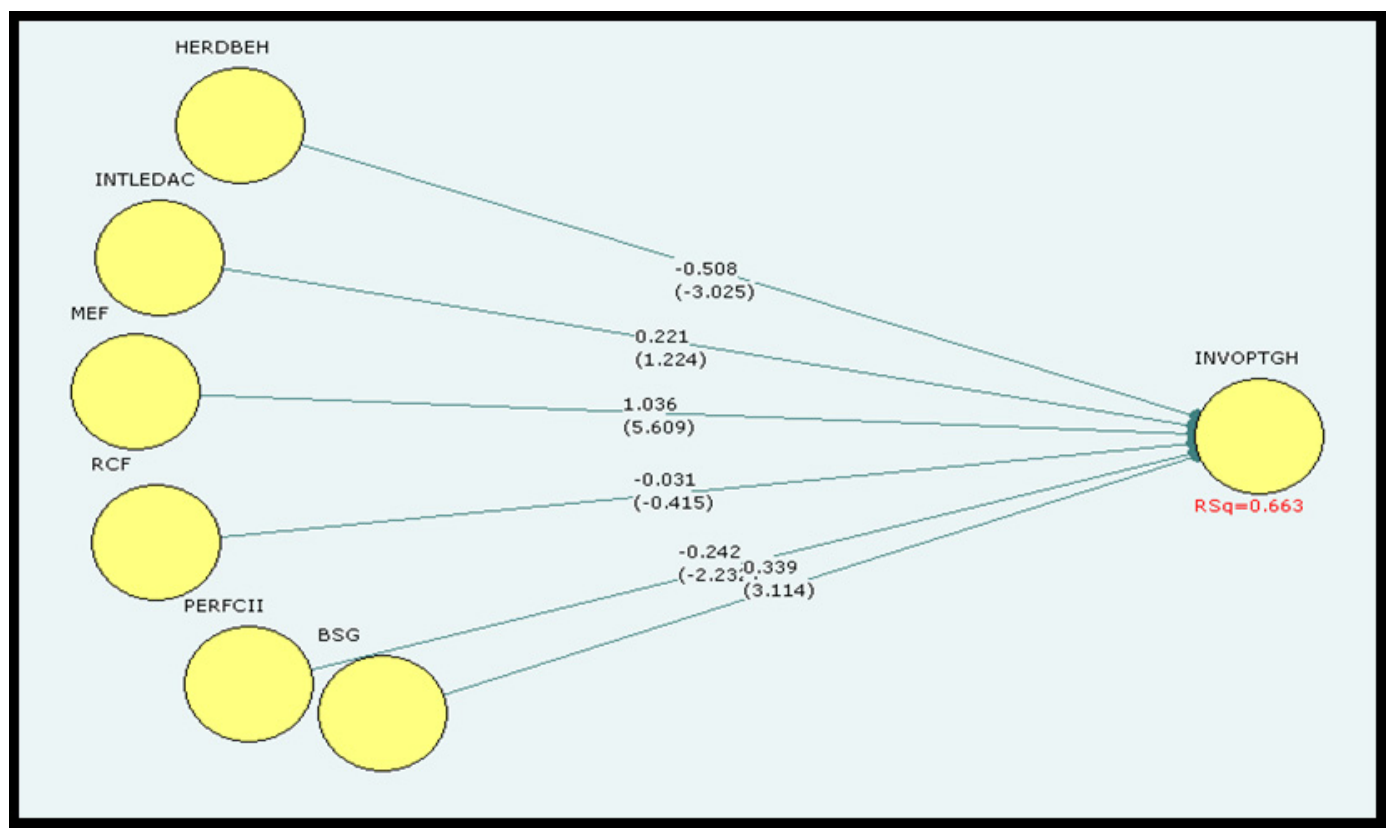

Figure 1. Validation of model 